\title{
Strategi Pemasaran Online UMKM Makanan (Studi Kasus di Kecamatan Cibinong)
}

\author{
Food Online Marketing Strategy for MSME (Case Study in Cibinong District)
}

\author{
Teguh Febrianto Setiawan ${ }^{1 *}$, Budi Suharjo ${ }^{2 *}$, dan Muhammad Syamsun ${ }^{3 *}$ \\ ${ }^{1}$ Program Studi Magister Pengembangan Indsutri Kecil Menengah, SPs IPB \\ ${ }^{2}$ Departemen Matematika, Fakultas Matematika dan Ilmu Pengetahuan Alam, IPB \\ ${ }^{3}$ Departemen Manajemen, Fakultas Ekonomi dan Manajemen, IPB \\ \#Jl. Kaamper Kampus IPB Darmaga Bogor 16680
}

\begin{abstract}
ABSTRAK
Pemasaran online (OL) merupakan metode pemasaran dengan media OL dan berbasis elektronik. Penelitian bertujuan (1) Mengkaji efektivitas pemasaran OL dalam meningkatkan pendapatan perusahaan, (2) Mendeskripsikan produk yang memiliki potensi pemasaran secara OL, (3) Mengidentifikasi faktorfaktor yang berpengaruh dalam menyusun strategi pemasaran OL, dan (4) Memberikan rekomendasi alternatif strategi pemasaran OL untuk diterapkan di Usaha Mikro Kecil dan Menengah (UMKM). Penelitian dilakukan pada 10 UMKM (purposif) yang ada di Kecamatan Cibinong Kabupaten Bogor, Propinsi Jawa Barat, pada bulan April-Agustus 2018. Metode analisis meliputi analisis deskriptif, analisis isi (content analysis), analisis Strength, Weaknesses, Opportunity, and Threat (SWOT) dan Analytic Hierarchy Process (AHP). Berdasarkan analisis, pemasaran OL berhasil meningkatkan pendapatan responden 10-32\%. Hasil telaah isi, UMKM responden sudah mengetahui pentingnya menampilkan visualisasi produk secara menarik dengan menampilkan deskripsi dan gambar yang dapat mengundang konsumen untuk membeli, namun belum sepenuhnya dioptimalkan melalui fasilitas Google Review Knowledge Pannel. Berdasarkan analisis SWOT didapatkan strategi: (a) Pengembangan usaha dengan dukungan sumber daya manusia (SDM) dan media pemasaran yang tersedia, (b) Pengembangan usaha dengan sistem (OL), (c) Peningkatan skala usaha dengan memanfaatkan modal, (d) Peningkatan skill dan pengetahuan sistem OL, (e) Peningkatan modal usaha dan tampilan promosi produk dalam peningkatan omzet, (f) Pengembangan usaha melalui varian produk, cita rasa dan promosi (g) Peningkatan kapasitas usaha dan layanan (Delivery), (h) Peningkatan kerjasama promosi produk OL, (i) Peningkatan inovasi dan varian produk baru. Alternatif metode pemasaran OL UMKM makanan di Kecamatan Cibinong yang dipilih berdasarkan AHP berturut-turut adalah media Grab-food. Prioritas kedua menggunakan sosial media (facebook, instagram, Youtube dll). Prioritas ketiga menggunakan media Google Search Engine Optimization (SEO). Prioritas keempat menggunakan website dan prioritas kelima direct contact.
\end{abstract}

Kata kunci: AHP, pemasaran online, sosial media, SWOT, telaah konten, UMKM

\section{ABSTRACT}

Online marketing is a method of marketing using online (OL) and electronic media. This study aims to, (1) Assess the effectiveness of (OL) marketing in increasing corporate income, (2) Describe products that have OL marketing potential, (3) Identify influential factors in developing OL marketing strategies, and (4) Providing recommendations for alternative OL marketing strategies to be applied in MSMEs. This research was conducted on 10 MSMEs in Cibinong Sub-district, Bogor Regency, West Java Province, from April to August 2018. The method of analysis consists of descriptive analysis, content analysis, Strength, Weaknesses, Opportunity, and Threat (SWOT) analysis and Analytic Hierarchy Process (AHP). Based on the analysis of research data it is known that OL marketing successfully increases income for respondents by $10 \%$ to $32 \%$. The results of content analysis found that the respondents' MSMEs already knew the importance of attracting product visualization by displaying descriptions and images that could invite consumers to buy, but not fully optimized yet through the Google Review Knowledge Panel facility. Based on the SWOT analysis, strategies were obtained: (a) Business Development with support of available Human Resource (HR) \& Marketing Media Support, (b) Business Development System (OL), (c) Business 
Scale Up by Utilizing Capital, (d) Skill Improvement and OL System Knowledge, (e) Increased Business Capital and Product Promotion Display in order increasing turnover, (f) Business Development through Product Variants, Taste and Promotions (g) Increasing business capacity and services (Delivery), (h) Increasing cooperation in OL product promotion, (i) Increasing innovation and new product variants. The alternative method of OL marketing of food MSMEs in Cibinong Sub district chosen based on AHP respectively is Grab-food media. The second priority is to use social media (Facebook, Instagram, Youtube etc.). The third priority is to use Google SEO media. The fourth priority is to use a website and the fifth priority is direct contact.

Key words: AHP, content review, MSMEs, online marketing, social media, SWOT

\section{PENDAHULUAN}

Peningkatan penyebaran akses internet diiringi pula oleh mulai tumbuhnya jumlah pedagang yang berjualan secara online, sehingga menimbulkan persaingan antar penjual. Kondisi tersebut menuntut perusahaan mengikuti keinginan dan kebutuhan konsumen yang semakin kompleks.

Menurut Ustadiyanto (2007), berdasarkan tujuan pembeliannya, konsumen e-business bisa dibedakan menjadi dua, yaitu: (1) konsumen individual, yang melakukan pembelian untuk keperluan konsumsi pribadi dan/atau rumah tangganya; (2) konsumen organisasional, melakukan pembelian untuk tujuan dijual lagi, disewakan, diproses lebih lanjut, digunakan untuk melayani masyarakat, dan tujuan bisnis atau organisasional lainnya.

Usaha, Mikro, Kecil dan Menengah (UMKM) makanan merupakan salah satu unit usaha yang saat ini banyak tumbuh dan berkembang, serta mulai merambah media OL. Salah satu faktor yang memicu pertumbuhan UMKM adalah adanya berbagai media promosi OL, termasuk ojek OL (Grabfood dan Gofood). Kajian faktor internal dan eksternal dalam pemasaran OL UMKM makanan di Kecamatan Cibinong menjadi sangat penting dalam upaya mengetahui berbagai faktor terkait pemasaran OL, khususnya UMKM makanan. Untuk itu kajian ini dilakukan pada 10 UMKM makanan yang telah terdaftar dan telah melakukan pemasaran OL melalui media GoFood. Berdasarkan uraian tersebut, tujuan penelitian ditetapkan sebagai berikut:

1. Mengkaji efektivitas pemasaran OL dalam meningkatkan pendapatan perusahaan.

2. Mendeskripsikan produk yang memiliki potensi pemasaran secara OL.

3. Mengidentifikasi faktor-faktor yang berpengaruh dalam menyusun strategi pemasaran OL.

4. Menyusun alternatif strategi pemasaran OL oleh UMKM.

\section{METODE PENELITIAN}

Penelitian dilakukan di Kec. Cibinong dengan metode sampling, karena memiliki UMKM makanan cukup banyak dan berkembang. Penelitian dilaksanakan pada bulan April-Agustus 2018.

Menurut Sugiyono (2010), metode pengumpulan data adalah teknik atau cara yang dilakukan untuk mengumpulkan data dengan tujuan tertentu. Pengumpulan data yang dikembangkan dalam penelitian Strategi Pemasaran OL UMKM Makanan di Kecamatan Cibinong meliputi (1) Metode studi pustaka (desk study), (2) Metode survei (wawancara), dan (3) Metode observasi. Metode pengumpulan data dilakukan secara purposive sampling yang melibatkan ahli (expert), pengusaha (owner) dan karyawan (staf).

Menurut Sugiyono (2010), analisis data adalah metode atau cara untuk mengolah sebuah data menjadi informasi, sehingga karakteristik data tersebut menjadi mudah untuk dipahami dan juga bermanfaat untuk menemukan solusi permasalahan, terutama masalah penelitian.

\section{Efektivitas Pemasaran OL UMKM Makanan}

Kajian efektivitas pemasaran OL UMKM makanan di Kecamatan Cibinong, dilakukan untuk mengkaji efektivitas media OL dalam meningkatkan omzet/penjualan. Metode analisis dilakukan dengan analisis pendapatan melalui pendekatan survei. Survei dilakukan terhadap 10 UMKM makanan, yakni Sukahati Cafe, Bakso Malang Pak Imo \& Pempek Faras, Istana Martabak, Wedang Jahe Si Eprit, Bebek Goreng Kodim, Bakmi Abun 69, Restoran Mbolijo, Soto Ibu Rahayu, Pempek QHD dan RM Padang Nur Putra.

\section{Mendeskripsikan produk yang melakukan pemasaran OL}

Kajian deskripsi produk UMKM makanan dimaksudkan untuk mengetahui tampilan jenis produk yang dipasarkan secara OL. Metode analisis dilakukan dengan pendekatan telaah content 


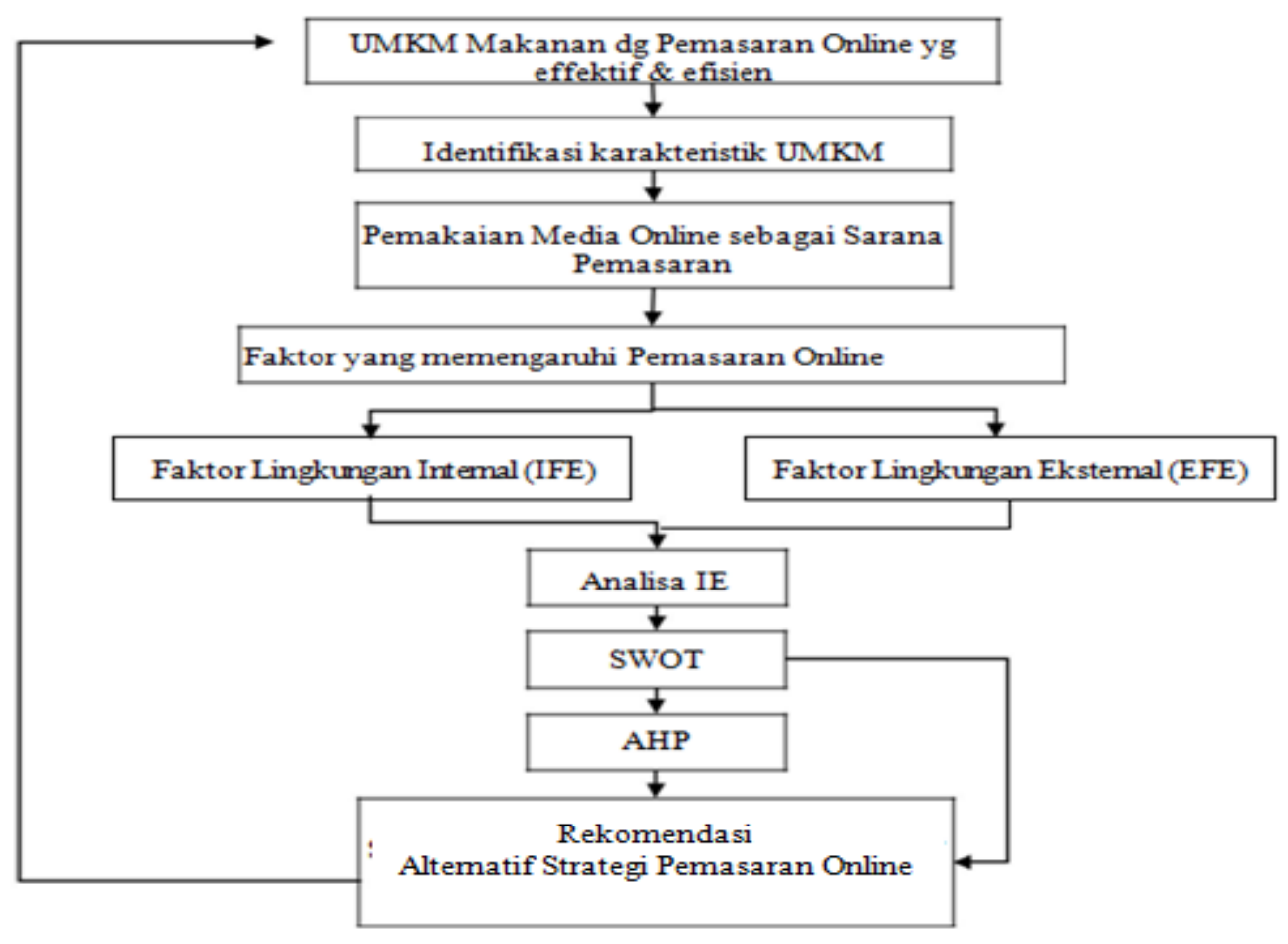

Gambar 1. Hirarki/struktur kajian strategi pemasaran OL UMKM makanan

(analisis isi). Tampilan produk menjadi kajian utama dalam analisis ini.

\section{Identifikasi Faktor-Faktor Pemasaran OL UMKM Makanan}

Identifikasi faktor-faktor pemasaran OL UMKM makanan untuk menganalisis faktor-faktor yang berpengaruh terhadap pengembangan usaha UMKM makanan di Kecamatan Cibinong. Pendekatan strengths, weaknesses, opportunities dan threats (SWOT) meliputi data internal dan ekstrnal yang menjadi faktor kunci dan terkait dengan proses pemasaran UMKM Makanan. Data dianalisis dengan matriks Internal Factor Evaluation (IFE), External Factor Evaluation (EFE), Internal External (IE), dan Strength, Weaknesses, Opportunity, and Threat (SWOT), melalui tahapan berikut:

\section{Tahapan input}

Tahapan ini dilakukan dengan memasukkan faktor-faktor yang terkait dengan kekuatan, kelemahan, peluang dan ancaman seperti dimuat pada Tabel 1.

\section{Tahapan Pencocokan}

a. Matriks SWOT

Matriks SWOT menurut David (2010) terdiri atas sembilan sel, terdapat empat sel faktor utama, empat sel strategi dan satu sel yang dibiarkan kosong (sel kiri atas). Keempat sel strategi, diberi nama SO, WO, ST dan WT, dikembangkan dari empat sel faktor utama, seperti $\mathrm{S}, \mathrm{W}, \mathrm{O}$, dan $\mathrm{T}$ Gambar 2).

Tabel 1. Matriks EFE dan Matriks IFE

\begin{tabular}{|c|c|c|c|}
\hline $\begin{array}{c}\text { Faktor Intemal/Ekstemal } \\
\text { Utama }\end{array}$ & $\begin{array}{l}\text { Bobot } \\
\text { (a) }\end{array}$ & $\begin{array}{l}\text { Peringkat } \\
\text { (b) }\end{array}$ & $\begin{array}{c}\text { Nilai Tertimbang } \\
(\mathrm{a} \times \mathrm{x})\end{array}$ \\
\hline \multicolumn{4}{|l|}{ Kekuatan/Peluang } \\
\hline \multicolumn{4}{|l|}{1.} \\
\hline \multicolumn{4}{|l|}{ 2. ................. } \\
\hline \multicolumn{4}{|l|}{ n. .................. } \\
\hline \multicolumn{4}{|l|}{ Kelemahan/Ancaman } \\
\hline \multicolumn{4}{|l|}{ 1. .................... } \\
\hline \multicolumn{4}{|l|}{ 2. ............... } \\
\hline \multicolumn{4}{|l|}{ n. ................ } \\
\hline Total & & & \\
\hline
\end{tabular}

\begin{tabular}{|l|l|l|}
\hline EFE IFE & \multicolumn{1}{|c|}{ Kekuatan(S) } & Kelemahan (W) \\
\hline Peluang (O) & $\begin{array}{l}\text { STRATEGI SO } \\
\begin{array}{l}\text { Menciptakan strategi } \\
\text { menggunakan kekuatan } \\
\text { untuk memanfaatkan } \\
\text { peluang }\end{array}\end{array}$ & $\begin{array}{l}\text { STRATEGI WO } \\
\text { Menciptakan strategi } \\
\text { yang meminimalkan } \\
\text { kelemahan untuk } \\
\text { memanfaatkan peluang }\end{array}$ \\
\hline Ancaman (T) & $\begin{array}{l}\text { STRATEGI ST } \\
\text { Menciptakan strategi yang } \\
\text { menggunakan kekuatan } \\
\text { untukmengatasi ancaman }\end{array}$ & $\begin{array}{l}\text { STRATEGI WT } \\
\text { Menciptakan strategi } \\
\text { yang meminimalkan } \\
\text { kelemahan dan } \\
\text { menghindari ancaman }\end{array}$ \\
\hline
\end{tabular}

Sumber: David (2010)

Gambar 2. Matriks SWOT

b. Matriks Internal Eksternal (IE)

Menurut David (2010), Matriks IE terdiri atas dua dimensi, yaitu total skor dari matriks IFE pada sumbu $x$ dan total skor dari matriks EFE pada sumbu y. Pada sumbu $x$ dari matriks IE, skor bobot 
IFE total 1,0-1,99 menunjukkan posisi internal adalah lemah; skor 2,0-2,99 posisinya dianggap sedang dan skor 3,0-4,0 adalah posisi kuat. Pada sumbu y, skor bobot EFE total 1,0-1,99 adalah posisi rendah; skor 2,0-2,99 dianggap posisi sedang dan skor 3,0-4,0 adalah posisi tinggi (Gambar 3).

\section{Alternatif Strategi Pemasaran OL UMKM Makanan}

Metode analisis data yang digunakan dalam kajian Alternatif Strategi Pemasaran OL UMKM Makanan di Kecamatan Cibinong, dilakukan dengan pendekatan AHP (Analytic Hierarchy Process). Menurut Marimin (2004) AHP memiliki banyak keunggulan dalam menjelaskan proses pengambilan keputusan, karena dapat digambarkan secara grafis, sehingga mudah dipahami oleh semua pihak yang terlibat dalam pengambilan keputusan (Gambar 4).

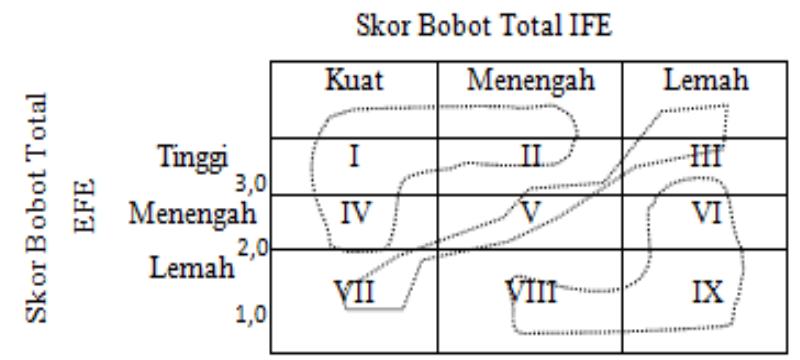

Sumber: David (2010)

\section{HASIL DAN PEMBAHASAN}

Cibinong merupakan salah satu dari 40 kecamatan di Kabupaten Bogor Provinsi Jawa Barat, Indonesia, yang berfungsi sebagai pusat pemerintahan (ibukota kabupaten).

\section{Demografis Penduduk Cibinong}

Sebagai daerah urban yang baru berkembang seiring dengan bertumbuhnya ibukota Jakarta ke arah Selatan, maka sebaran penduduk Cibinong dapat dilihat pada Tabel 2.

Tabel 2. Daftar penduduk menurut kelompok usia

\begin{tabular}{lll}
\hline $\begin{array}{l}\text { Kelompok } \\
\text { Umur (Tahun) }\end{array}$ & $\begin{array}{l}\text { Jumlah } \\
\text { Penduduk }\end{array}$ & $\begin{array}{l}\text { Kelompok } \\
\text { Generasi }\end{array}$ \\
\hline $0-4$ & 40,809 & Generasi Z \\
$5-9$ & 38,063 & \\
$10-14$ & 34,427 & \\
$15-19$ & 35,379 & \\
$20-24$ & 39,091 & \\
\hline $25-29$ & 38,956 & Generasi Y \\
$30-34$ & 39,948 & \\
$35-39$ & 38,679 & \\
\hline $40-44$ & 33,705 & Generasi X \\
$45-49$ & 25,325 & \\
$50-54$ & 17,820 & \\
$55++$ & 30,054 & \\
\hline Sumber: BPS Kab. Bogor (2017).
\end{tabular}

Gambar 3. Matriks internal eksternal (IE)

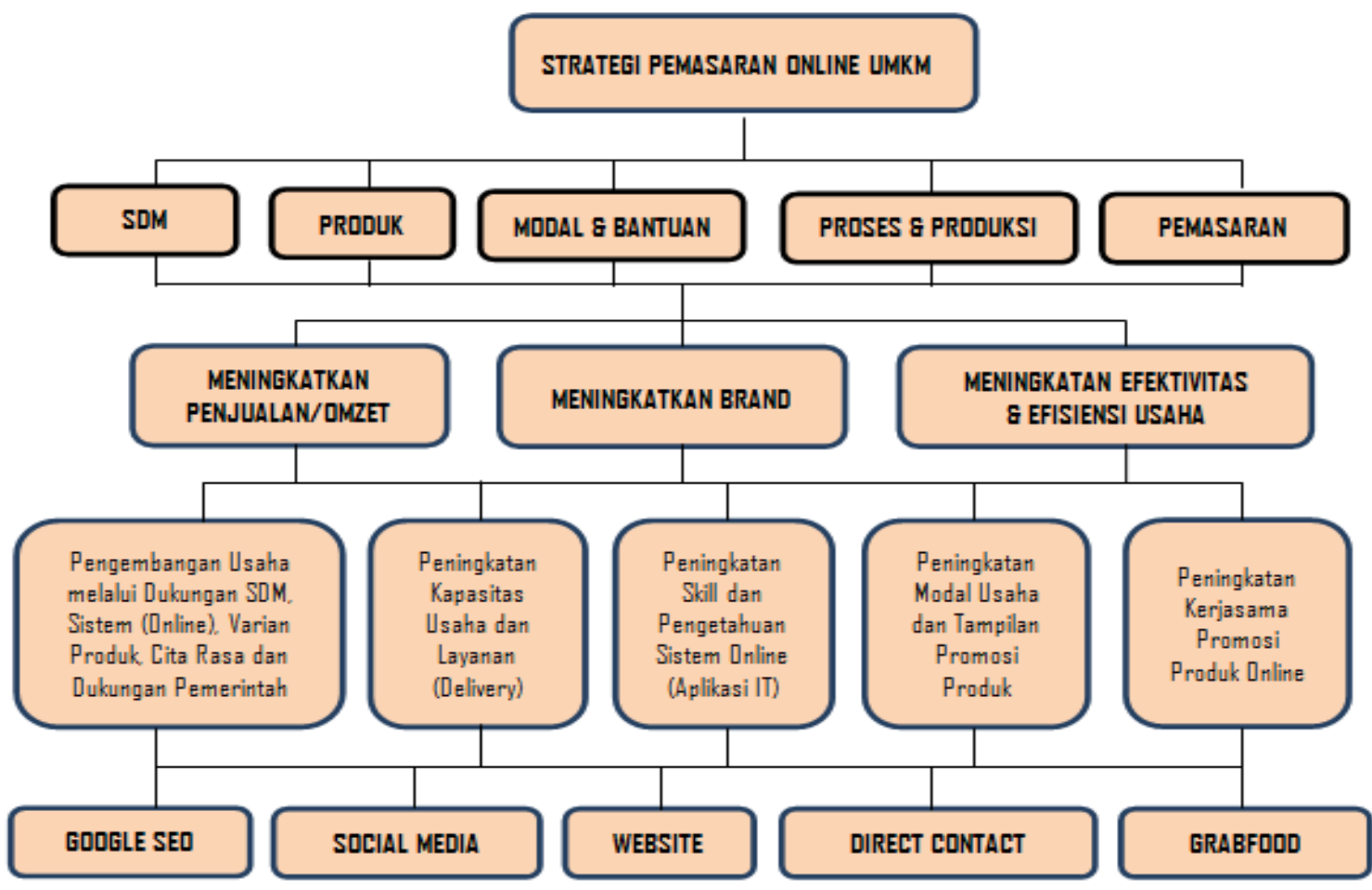

Gambar 4. Struktur AHP pemasaran OL UMKM makanan 


\section{Gambaran UMKM Makanan di Kec. Cibinong}

Survei terhadap 10 UMKM makanan di Kecamatan Cibinong dimuat pada Tabel 3. Berdasarkan Tabel 3, terlihat responden survei beragam mulai dari restoran (tiga responden) yang telah terdaftar di Dinas UMKM, Warung makan (enam responden), dan gerobak pinggir jalan (satu responden), rentang usia dalam penjualan OL juga beragam, yaitu mulai satu bulan sampai dengan satu tahun, hal ini dilakukan untuk mendapatkan keterwakilan data dari berbagai tipe UMKM. Penggunaan media OL untuk pemasaran terbatas melalui GoFood.

\section{Hasil Analisis}

Analisis efektivitas pemasaran OL dalam meningkatkan pendapatan perusahaan

Sebagai salah satu kegiatan usaha, pemasaran OL juga dimaksudkan untuk meningkatkan penjualan, sehingga pendapatan usaha juga meningkat. Berdasarkan hasil survei didapatkan data pada Tabel 4. Pada Gambar 5 terlihat penjualan OL UMKM yang menjadi responden survei meningkat $10-32 \%$ secara bervariasi terhadap berbagai jenis usaha.

\section{Analisis tampilan produk yang memiliki potensi pemasaran $\mathrm{OL}$}

Fungsi media OL untuk menyampaikan pesan tentang produk yang ditawarkan kepada konsumen, dengan cara sedemikian rupa, sehingga konsumen tertarik untuk melakukan pembelian. Sebagai perbandingan, pada Tabel 5 disampaikan perbandingan metode pemasaran konvensional dengan media OL.

Tabel 3. UMKM responden survei

\begin{tabular}{|c|c|c|c|c|}
\hline Nama UMKM & $\begin{array}{l}\text { Umur } \\
\text { Usaha }\end{array}$ & $\begin{array}{l}\text { Umur } \\
\text { Online }\end{array}$ & $\begin{array}{l}\text { Media Online } \\
\text { saat ini }\end{array}$ & Jenis Usaha \\
\hline Sukahati Cafe & 2 Tahun & 7 Bulan & Go Food & Restoran-Terdaftar di PEMDA \\
\hline $\begin{array}{l}\text { Bakso Malan Pak Imo \& } \\
\text { Pempek Faras }\end{array}$ & 6 Tahun & 4 Bulan & Go Food & $\begin{array}{l}\text { Warung Bakso- Belum Terdaftar } \\
\text { di PEMDA }\end{array}$ \\
\hline Istana Martabak & 2 Bulan & 1 Bulan & Go Food & $\begin{array}{l}\text { Warung Martabak- Belum } \\
\text { Terdaftar di PEMDA }\end{array}$ \\
\hline Wedang Jahe Si Eprit & 7 Bulan & 6 Bulan & Go Food & $\begin{array}{l}\text { Gerobak Wedang Jahe- Belum } \\
\text { Terdaftar di PEMDA }\end{array}$ \\
\hline Bebek Goreng Kodim & 4 Tahun & 3 Bulan & Go Food & $\begin{array}{l}\text { Warung Makan- Belum Terdaftar } \\
\text { di PEMDA }\end{array}$ \\
\hline Bakmi Abun 69 & 2 Tahun & 1 Tahun & Go Food & $\begin{array}{l}\text { Warung Makan- Belum Terdaftar } \\
\text { di PEMDA }\end{array}$ \\
\hline Restoran Mbolijo & 4 Tahun & 6 Bulan & Go Food & Restoran-Terdaftar di PEMDA \\
\hline Soto Ibu Rahayu & 1 Tahun & 1 Bulan & Go Food & Restoran-Terdaftar di PEMDA \\
\hline Pempek QHD & 6 Bulan & 5 Bulan & Go Food & $\begin{array}{l}\text { Warung Makan- Belum Terdaftar } \\
\text { di PEMDA }\end{array}$ \\
\hline RM Padang Nur Putra & 6 Bulan & 1 Bulan & Go Food & $\begin{array}{l}\text { Warung Makan- Belum Terdaftar } \\
\text { di PEMDA }\end{array}$ \\
\hline
\end{tabular}

Tabel 4. Perbandingan pendapatan sebelum dan setelah OL

\begin{tabular}{lrrc}
\hline \multicolumn{1}{c}{ Nama UMKM } & $\begin{array}{c}\text { Pedapatan } \\
\text { Sebelum OL } \\
\text { (Rp/bulan) }\end{array}$ & $\begin{array}{c}\text { Pendapatan } \\
\text { Setelah OL } \\
\text { (Rp/bulan) }\end{array}$ & $\begin{array}{c}\text { Persentase } \\
\text { Kenaikan } \\
\text { Pendapatan (\%) }\end{array}$ \\
\hline Sukahati Café (SC) & 65.000 .000 & 75.000 .000 & 15,38 \\
Bakso Malang Pak Imo \& & 33.000 .000 & 38.000 .000 & 15,15 \\
Pempek Faras (BM) & & & \\
Istana Martabak (IM) & 60.000 .000 & 66.000 .000 & 10,00 \\
Wedang Jahe Si Eprit (WJ) & 4.000 .000 & 5.300 .000 & 32,50 \\
Bebek Goreng Kodim (BK) & 63.000 .000 & 70.000 .000 & 11,11 \\
kmi Abun 69 (BA) & 45.000 .000 & 50.000 .000 & 11,11 \\
Restoran Mbolijo (RM) & 65.000 .000 & 75.000 .000 & 15,38 \\
Soto Ibu Rahayu (SR) & 100.000 .000 & 125.000 .000 & 25,00 \\
Pempek QHD (PQ) & 7.500 .000 & 9.500 .000 & 26,67 \\
RM Padang Nur Putra (NP) & 30.000 .000 & 34.000 .000 & 13,33 \\
\hline
\end{tabular}




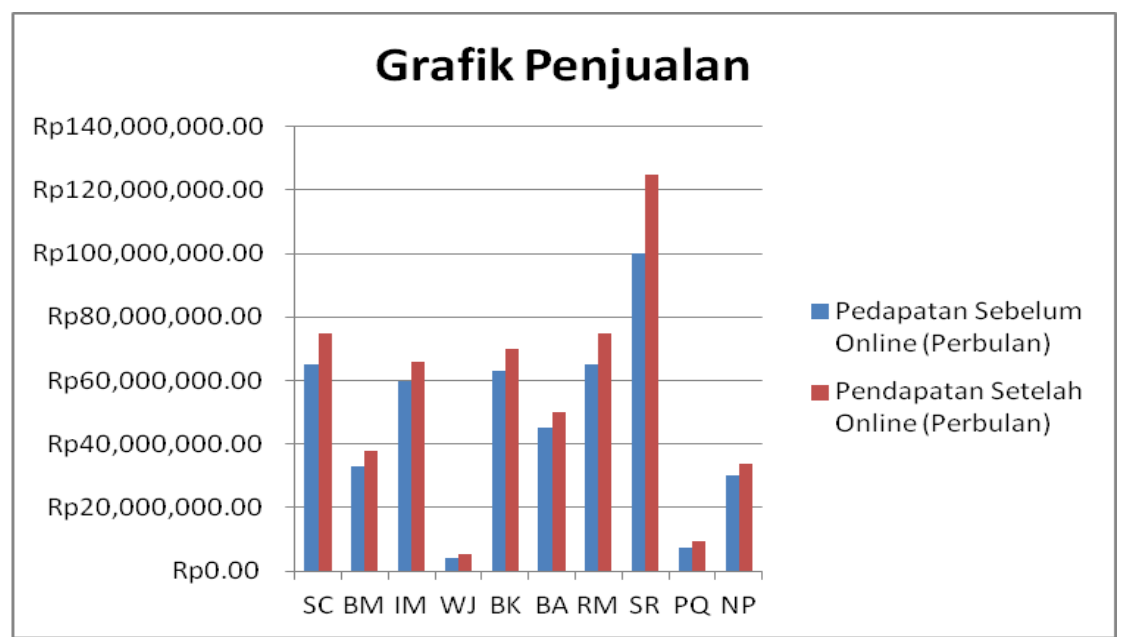

Gambar 5. Grafik penjualan

Tabel 5. Perbandingan metode konvensional dengan OL

\begin{tabular}{lll}
\hline \multicolumn{1}{c}{ Proses } & \multicolumn{1}{c}{$\begin{array}{c}\text { Metode } \\
\text { Konvensional }\end{array}$} & Metode Online \\
\hline Informasi & - Leaflet & - Facebook \\
Produk/Iklan & - Iklan Radio & - Instagram \\
& - Surat Kabar & - Twitter \\
& & - GoFood \\
& & - GrabFood \\
\hline Pembelian/ & - Telepon & - GoFood \\
Transaksi & - Transfer & - GrabFood \\
& - Tunai & - Tokopedia \\
& & - Bukalapak \\
\hline Pengiriman/ & - Pos/Tiki/JNE & - GoFood \\
Delivery & & - GrabFood \\
\hline Testimoni/ & - Surat & - Google Review \\
Penilaian & Pembaca & - Facebook \\
& & - Instagram \\
& & - Twitter \\
\hline
\end{tabular}

Sesuai dengan penjelasan di atas salah satu tahapan adalah penyampaian informasi produk/ iklan. Pada tahap ini sebuah produk ditampilkan dengan visualisasi menarik disertai dengan ilustrasi/deskripsi produk, seperti bahan baku, rasa dan harga. Semakin menarik informasi ditampilkan akan memberikan kesempatan yang lebih besar untuk konsumen melanjutkan ke tahap selanjutnya, yaitu tahap pembelian atau transaksi. Sebuah iklan dapat dikatakan efektif, saat iklan tersebut dapat diingat oleh pengunjung dan memberikan tingkat kesadaran kepada pengunjung telah melihat iklan yang dipasang pada sebuah situs web (Briggs \& Hollis et al. 1997). Dapat dikatakan impresi sebuah produk yang ditawarkan melalui media OL terkait dengan tingkat kesadaran pengunjung/konsumen terhadap kehadiran iklan tersebut (ad recognition). Menurut McCoy et al. (2016), tingkat ad recognition didapatkan dari kemampuan partisipan mengidentifikasi iklan yang diletakkan dan tampilan iklan tersebut. Sesuai penjelasan tersebut, deskripsi suatu produk pada media OL berpengaruh pada kesadaran (ad recognition) pengunjung. Kesadaran pengunjung dapat dibangun dengan menampilkan deskripsi ciri-ciri berikut:

1. Sesuai fakta/jujur dan obyektif

2. Singkat jelas padat dan mudah dipahami

3. Tidak mengandung ungkapan menyinggung pihak lain

4. Menggunakan kata-kata sopan dan menarik

Bagian-bagian yang harus ada dalam suatu produk makanan yang akan ditampilkan secara OL adalah:

1. Nama produk

2. Bahan pembuat produk dan rasa

3. Harga produk

Selain penggunaan deskripsi yang menarik, tampilan produk secara visual/gambar juga menentukan keberhasilan pemasaran suatu produk secara OL. Dalam periklanan, bahasa dan gambar saling terkait erat dan saling menjelaskan (Romer dan Baumgart dalam Sari 2012). Menurut Janich dalam Sari (2012), selain unsur-unsur verbal dalam iklan terdapat unsur-unsur nonverbal yang berperan penting dalam komunikasi dengan klasifikasikan berikut:

1. Key-Visual; gambar produk utama yang ingin ditampilkan, biasanya terletak di bagian paling depan gambar atau diposisikan lebih mencolok. Sebagai contoh pada produk makanan adalah menu utama yang akan dijual.

2. Catch-Visual; gambar pendukung, memberikan assosiasi tambahan tanpa menutup daya tarik gambar produk utama. Sebagai contoh untuk produk makanan adalah wadah atau potongan-potongan cabai, tomat atau rempah- 
rempah disekeliling menu utama sebagai pemanis.

3. Focus-Visual; gambar dalam potongan kecil yang berdiri sendiri dan merupakan bagian penting sebuah produk. Sebagai contoh gambar meja ditengah-tengah taman sebagai tempat meletakkan makanan utama.

Sesuai dengan penjelasan di atas, maka untuk mendapatkan komposisi menarik dari sebuah gambar/visual produk makanan yang akan ditampilkan secara OL, gerai-gerai berusaha sebaik mungkin menampilkan foto menarik, yaitu menyewa fotografer profesional, membuat seting pemotretan dan editing pada gambar (Tabel 6).

Tabel 6. Tampilan visual dari menu yang ditawarkan

\begin{tabular}{lcc}
\hline \multicolumn{1}{c}{ Nama UMKM } & $\begin{array}{c}\text { Menampilkan } \\
\text { Foto }\end{array}$ & $\begin{array}{c}\text { Deskripsi } \\
\text { Produk }\end{array}$ \\
\hline $\begin{array}{l}\text { Sukahati Cafe } \\
\text { Bakso Malang Pak }\end{array}$ & Ada & Ada \\
Imo \& Pempek Faras & Ada & Ada \\
Istana Martabak & Ada & Ada \\
Wedang Jahe Si Eprit & Tidak Ada & Ada \\
Bebek Goreng Kodim & Ada & Ada \\
Bakmi Abun 69 & Ada & Ada \\
Restoran Mbolijo & Ada & Ada \\
Soto Ibu Rahayu & Ada & Ada \\
Pempek QHD & Ada & Ada \\
RM Padang Nur Putra & Ada & Ada \\
\hline
\end{tabular}

Dalam survei yang telah dilakukan (Gambar 6) adalah contoh visualisasi produk yang dijual pada UMKM makanan yang menjadi responden survei. Dari tampilan pada Gambar 6 dapat diketahui bahwa UMKM telah menampilkan visualisasi produk dan deskripsi agar konsumen tertarik dan melakukan pembelian.

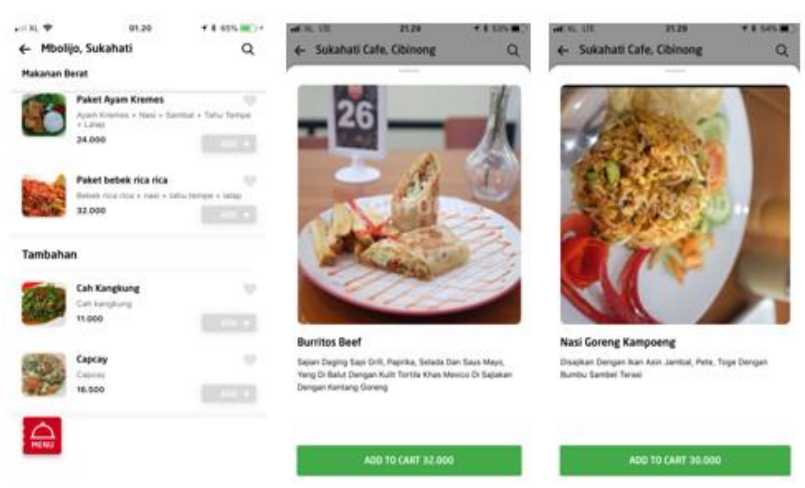

Gambar 6. Tampilan menu pada media OL

Tingkat awareness/recognition terhadap UMKM dapat dengan mudah diidentifikasi melalui fitur Google Review "Knowledge Pannel".
Fitur Google tersebut berisi informasi mengenai bisnis yang dijalankan, foto tampilan, alamat, peta lokasi dan hasil review, serta testimoni dari pelanggan. Semakin tinggi jumlah bintang dan semakin banyak testimoni yang diberikan, maka tingkat awareness/recognition terhadap sebuah UMKM akan semakin baik. Pada Gambar 7 diketahui bahwa Sukahati Cafe mendapatkan 4.1 bintang dan 335 testimoni.
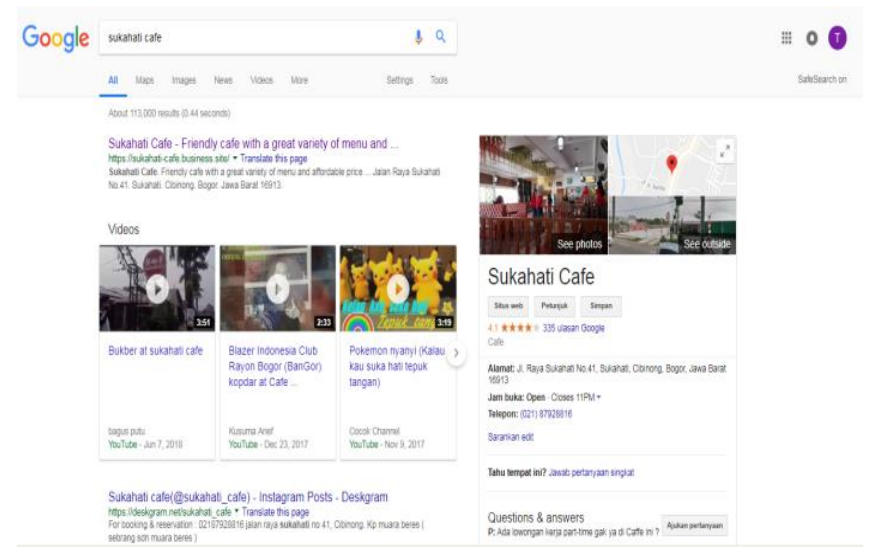

Gambar 7. Tampilan Google Review Sukahati Cafe

Berdasarkan survei, Tabel 7 menunjukkan review "Knowledge Panel" untuk UMKM makanan yang menjadi responden survei.

Tabel 7. Penilaian Google review knowledge panel

\begin{tabular}{lll}
\hline \multicolumn{1}{c}{ Nama UMKM } & \multicolumn{1}{c}{$\begin{array}{c}\text { Jumlah } \\
\text { Bintang }\end{array}$} & \multicolumn{1}{c}{$\begin{array}{c}\text { Jumlah } \\
\text { Testimoni }\end{array}$} \\
\hline Sukahati Cafe & 4,1 & 335 \\
Bakso Malan Pak & 4,1 & 1 \\
$\begin{array}{l}\text { Imo\&Pempek } \\
\text { Faras }\end{array}$ & & \\
$\begin{array}{l}\text { Istana Martabak } \\
\text { Wedang Jahe Si }\end{array}$ & Tidak tercantum & Tidak tercantum \\
Eprit & & Tidak tercantum \\
$\begin{array}{l}\text { Bebek Goreng } \\
\text { Kodim }\end{array}$ & 5 & 2 \\
$\begin{array}{l}\text { Bakmi Abun 69 } \\
\text { Restoran Mbolijo }\end{array}$ & 4,1 & \\
$\begin{array}{l}\text { Soto Ibu Rahayu } \\
\text { Pempek QHD }\end{array}$ & 4,2 & Tidak tercantum \\
RM Padang Nur & Tidak tercantum & Tidak tercantum \\
Putra & & \begin{tabular}{l} 
Tidak tercantum \\
\hline
\end{tabular} \\
\hline
\end{tabular}

Berdasarkan Tabel 7 diketahui bahwa empat dari 10 UMKM belum memanfaatkan fitur Google review "Knowledge Panel" secara maksimum. Strategi meningkatkan review melalui knowledge panel dilakukan secara organik (menunggu konsumen memberikan testimoni) atau secara stimulus melibatkan konsumen untuk memberikan testimoni sebagai bagian dari program promosi/bonus. 


\section{Identifikasi Faktor Internal dan Eksternal}

Identifikasi faktor internal dan eksternal merupakan upaya memperoleh gambaran faktorfaktor yang memengaruhi kegiatan promosi OL UMKM makanan di Kecamatan Cibinong. Faktorfaktor tersebut diperoleh dari hasil wawancara dengan pemilik (owner), manajer dan karyawan pada 10 UMKM makanan yang di survei. Hasilnya selanjutnya dikelompokkam dalam empat faktor utama, yakni Kekuatan (Strengths), Kelemahan (Weakness), Peluang (Oppportunities) dan Ancaman (Threats). Selanjutnya dilakukan penilaian dengan pembobotan dan rating, untuk mengetahui kedudukan faktor-faktor tersebut, serta pengaruh dari setiap peubah (variabel) dalam faktor yang dimuat pada Tabel 8 .

Hasil evaluasi faktor internal diperoleh nilai 2,2708, meliputi faktor kekuatan 1,4167 dan faktor kelemahan 0,8542. Berdasarkan nilai tersebut diketahui kedudukan faktor internal dalam pengembangan promosi OL UMKM makanan di Kecamatan Cibinong adalah tergolong lemah. David (2004) menyatakan bila total skor pembobotan IFE (internal factor evaluation) lebih dari (> $2,5)$ tergolong kuat, dan bila kurang dari $(<2,5)$ tergolong lemah. Dengan demikian faktor internal dikategorikan lemah pengaruhnya dalam pengembangan usaha UMKM makanan, khususnya terkait kegiatan promosi OL, meskipun nilainya relatif mendekati 2,5. Hasil evaluasi faktor internal tersebut menunjukkan faktor kekuatan yang memiliki nilai tertinggi adalah peubah pengetahuan dan skill SDM dalam operasional usaha, yakni $0,4167(41,67 \%)$ dan pada faktor kelemahan diperoleh nilai tertinggi adalah peubah minimnya modal alokasi khusus untuk pengembangan pemasaran OL yakni 0,2083 (20,83\%). Dengan demikian peubah tersebut merupakan peubah yang paling berpengaruh terhadap pengembangan usaha UMKM makanan di Kecamatan Cibinong, khususnya terkait kegiatan promosi OL.

Hasil evaluasi faktor eksternal diperoleh nilai 2,8542 meliputi faktor peluang 2,3333 dan faktor ancaman 0,8163. Berdasarkan nilai tersebut diketahui kedudukan faktor eksternal dalam pengembangan promosi OL UMKM makanan di Kecamatan Cibinong adalah tergolong kuat. Menurut David (2004), bila total skor pembobotan EFE (external factor evaluation) lebih dari $(>2,5)$ diangap kuat, dan bila kurang dari $(<2,5)$ dianggap lemah. Hasil evaluasi faktor eksternal, khususnya pada faktor peluang diperoleh nilai tertinggi, yaitu peubah kemajuan TI dengan nilai 0,4167 (41,67\%) dan pada faktor kelemahan diperoleh nilai tertinggi adalah peubah inovasi menu dan produk baru, yakni 0,1250 (12,50\%). Dengan demikian diperoleh gambaran bahwa peubah kemajuan TI dan peubah inovasi menu dan produk baru merupakan dua peubah yang sangat berpengaruh dari faktor eksternal terhadap pengembangan usaha UMKM makanan di Kecamatan Cibinong, khususnya kegiatan promosi OL. Peubah kemajuan TI merupakan sebuah keniscayaan seiring dengan perkembangan zaman yang saat ini memasuki era revolusi industri 4.0, dimana kemajuan TI saat ini begitu pesat. Peubah inovasi menu dan produk baru merupakan hal yang harus senantiasa dilakukan mengingat persaingan usaha dan passion dalam kuliner yang berkembang.

\section{Pemetaan Kedudukan IFE dan EFE}

Grafik kedudukan faktor IFE dan EFE memberikan gambaran kondisi saat ini, sehingga berbagai upaya dapat dilakukan untuk meningkatkan usaha tersebut. Hasil evaluasi faktor internal (IFE) diperoleh nilai 2,4792 dan faktor eksternal (EFE) diperoleh nilai 2,7551, sehingga diperoleh kedudukan strategi dan pengembangan promosi OL UMKM makanan di Kecamatan Cibinong dalam kuadran V (STABILITAS). Menurut David (2004), kuadran V merupakan kuadran stabilitas, yaitu kondisi yang relatif baik atau stabil untuk saat ini dan memiliki prospek dimasa mendatang. Pemetaan faktor internal dan eksternal dengan mengikuti kuadran matriks menurut Rangkuti (2015) diperoleh nilai faktor internal -0,4375 dan nilai faktor eksternal 1,0204, secara grafik terletak pada kuadran II (Gambar 9).

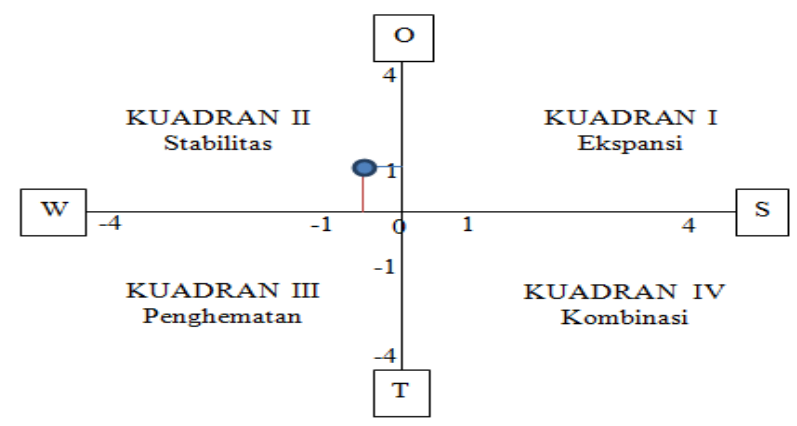

Gambar 9. Pemetaan faktor internal dan eksternal dalam diagram SWOT

Hasil pemetaan faktor internal dan eksternal pada matriks SWOT menunjukkan kedudukan faktor pengembangan usaha UMKM makanan terkait promosi OL berada pada kuadran II, yakni stabilitas. Menurut Rangkuti (2015), kuadran II menunjukkan berbagai ancaman, tetapi usaha tersebut masih memiliki kekuatan dari segi internal. 
Tabel 8. Pembobotan, rating dan skoring faktor internal dan ekternal

\begin{tabular}{|c|c|c|c|c|}
\hline No & IFAS \& EFAS & Nilai Bobot & Rating & Skor \\
\hline A & KEKUATAN & & & \\
\hline 1 & Pengetahuan dan skill SDM dalam operasional usaha & 0,1042 & 4 & 0,4167 \\
\hline 2 & Jumlah SDM & 0,0417 & 3 & 0,1250 \\
\hline 3 & Standar dan supplier bahan baku dalam menjamin mutu dan rasa & 0,0625 & 4 & 0,2500 \\
\hline 4 & Resep menu masakan & 0,0833 & 3 & 0,2500 \\
\hline 5 & Ketersediaan dan pemenuhan kebutuhan karyawan & 0,0625 & 3 & 0,1875 \\
\hline \multirow[t]{2}{*}{6} & Standar gaji dan bonus bagi karyawan (tenaga kerja) & 0,0625 & 3 & 0,1875 \\
\hline & Sub Total & & & 1,4167 \\
\hline B & KELEMAHAN & & & \\
\hline 1 & Rendahnya pengetahuan dan skill SDM dalam pemasaran OL & 0,1042 & 1 & 0,1042 \\
\hline 2 & Minimnya modal alokasi khusus untuk pengembangan pemasaran OL & 0,1042 & 2 & 0,2083 \\
\hline 3 & $\begin{array}{l}\text { Masih kurangnya tampilan produk yang dijual secara OL } \\
\text { menggunakan fotografer/narator khusus }\end{array}$ & 0,0417 & 1 & 0,0417 \\
\hline 4 & $\begin{array}{l}\text { Jumlah omzet penjualan OL dibandingkan offline }(<30 \% \text { dari omzet } \\
\text { total) }\end{array}$ & 0,0625 & 2 & 0,1250 \\
\hline 5 & $\begin{array}{l}\text { Rendahnya pengetahuan tentang pemasaran OL (Google SEO/Google } \\
\text { bisnis, iklan/ads social media marketting (facebook, instagram, twitter, } \\
\text { youtube), website profile dan order, iklan/ads direct customer contact } \\
\text { (SMS, whatapp, email) }\end{array}$ & 0,0625 & 1 & 0,0625 \\
\hline 6 & $\begin{array}{l}\text { Rendahnya pengetahuan tentang aplikasi pemasaran OL (GrabFood- } \\
\text { GoFood etc.) }\end{array}$ & 0,0625 & 1 & 0,0625 \\
\hline 7 & Belum adanya SOP dan job-description dalam proses produksi & 0,0208 & 2 & 0,0417 \\
\hline 8 & Rendahnya standar peralatan produksi & 0,0417 & 2 & 0,0833 \\
\hline 9 & $\begin{array}{l}\text { Rendahnya standar pengemasan (packaging) dan pengantaran produk } \\
\text { (delivery) }\end{array}$ & 0,0417 & 1 & 0,0417 \\
\hline \multirow[t]{3}{*}{10} & Banyaknya waktu yang dibutuhkan untuk menyiapkan produk & 0,0417 & 2 & 0,0833 \\
\hline & Sub Total & & & 0,8542 \\
\hline & Total IFE & 1,0000 & & 2,2708 \\
\hline $\mathrm{C}$ & PELUANG & & & \\
\hline 1 & Pendampingan dan training oleh pemerintah & 0,0417 & 3 & 0,1250 \\
\hline 2 & Modal pengembangan usaha tambahan dari bank/pemerintah & 0,0625 & 3 & 0,1875 \\
\hline 3 & $\begin{array}{l}\text { Penerima investor terpisah untuk pemasaran secara OL (kulina, } \\
\text { Madhang, etc) }\end{array}$ & 0,0208 & 3 & 0,0625 \\
\hline 4 & Media pemasaran OL (>3 media) & 0,0625 & 4 & 0,2500 \\
\hline 5 & Rencana pengembangan pemasaran OL ( $>3$ media ) & 0,0833 & 3 & 0,2500 \\
\hline 6 & Kemajuan TI & 0,1042 & 4 & 0,4167 \\
\hline 7 & Minat masyarakat dalam pemesanan OL & 0,0833 & 4 & 0,3333 \\
\hline 8 & Banyaknya layanan aplikasi OL yang tersedia & 0,0833 & 4 & 0,3333 \\
\hline 9 & Jaringan wifi (daring) yang berkembang pesat & 0,0625 & 4 & 0,2500 \\
\hline \multirow[t]{2}{*}{10} & Promosi/diskon khusus untuk produk tertentu atau produk baru & 0,0417 & 3 & 0,1250 \\
\hline & Sub Total & & & 2,3333 \\
\hline $\mathbf{D}$ & ANCAMAN & & & \\
\hline 1 & Jumlah produk yang dijual & 0,1042 & 1 & 0,1042 \\
\hline 2 & Makanan yang dipasarkan setiap hari terjual habis & 0,0417 & 3 & 0,0833 \\
\hline 3 & Inovasi menu dan produk baru & 0,0625 & 3 & 0,1250 \\
\hline 4 & Kegiatan survei kepuasan pelanggan & 0,0208 & 4 & 0,0417 \\
\hline 5 & Kompetitor mudah tumbuh dan berkembang & 0,0833 & 1 & 0,0833 \\
\hline \multirow[t]{3}{*}{6} & Peralatan produksi yang lebih efisien dan efektif & 0,0417 & 4 & 0,0833 \\
\hline & Sub Total & & & 0,5208 \\
\hline & Total EFE & 1,0000 & & 2,8542 \\
\hline
\end{tabular}


Strategi yang harus diterapkan adalah menggunakan kekuatan untuk memanfaatkan peluang jangka panjang dengan cara strategi diversifikasi (produk/ ekspansi pasar).

\section{Analisis Matriks SWOT}

Analisis matriks SWOT merupakan matriks penyusunan strategi faktor internal (Strengths-Weaknesses) dan faktor eksternal (Opportunities-Threats). Berdasarkan matriks SWOT, diperoleh empat strategi, yaitu strategi Strengths Opportunities (SO), strategi Strengths Threats (ST), strategi Weaknesses Opportunities (WO), dan strategi Weaknesses Threats (WT).

Matriks SWOT terkait pemasaran OL UMKM makanan di Kabupaten Bogor menghasilkan lima strategi berikut:

1. Pengembangan usaha dengan dukungan SDM \& media pemasaran yang tersedia.

2. Pengembangan usaha dengan sistem OL.

3. Peningkatan skala usaha dengan memanfaatkan modal.

4. Peningkatan skill dan pengetahuan sistem OL.

5. Peningkatan modal usaha dan tampilan promosi produk dalam peningkatan omzet.

6. Pengembangan usaha melalui varian produk, cita rasa dan promosi.

7. Peningkatan kapasitas usaha dan layanan (delivery).

8. Peningkatan kerjasama promosi produk OL.

9. Peningkatan inovasi dan varian produk baru.

Sembilan strategi tersebut merupakan hasil rumusan dari faktor internal (IFE) dan faktor eksternal (EFE). Strategi dalam kajian ini dimaksudkan sebagai rencana (planning) untuk mencapai tujuan. Menurut Mintzberg (1998), strategi sebagai rencana merupakan sebuah program atau langkah terencana (a directed course of action) untuk mencapai serangkaian tujuan atau cita-cita yang telah ditentukan, seperti halnya dengan konsep strategi perencanaan.

\section{Alternatif Strategi Pemasaran OL UMKM Makanan}

\section{Prioritas Faktor Pemasaran OL UMKM Makanan}

Menurut Kotler (2001), pemasaran OL adalah pemasaran yang dilakukan melalui sistem komputer OL interaktif yang menghubungkan konsumen dan penjual secara elektronik. Berbagai faktor pengembangan usaha UMKM makanan, meliputi pemasaran, SDM, produk, modal dan bantuan, serta proses dan produksi. Prioritas dari kelima faktor tersebut dimuat pada Gambar 10.

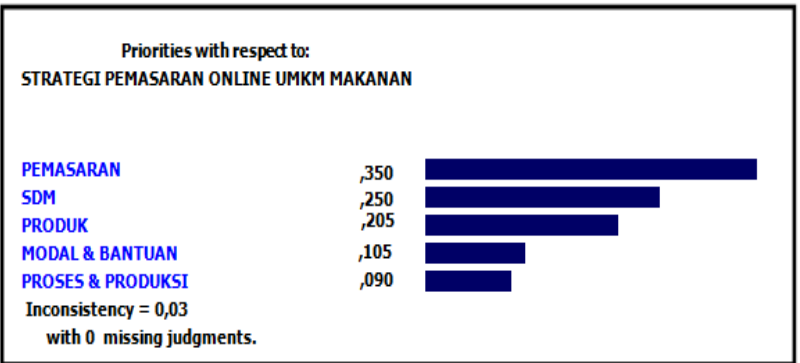

Gambar 10. Prioritas kriteria faktor pemasaran OL UMKM makanan

Hasil tersebut menunjukkan faktor pemasaran merupakan faktor utama dalam pengembangan UMKM makanan di Kecamatan Cibinong dengan nilai persentase mencapai 35,00\%. Prioritas kedua adalah faktor SDM (Sumber Daya Manusia) dengan nilai prioritas $25,00 \%$. Prioritas ketiga adalah faktor produk dengan nilai persentase $20,50 \%$. Selanjutnya adalah faktor modal dan bantuan dengan nilai persentase $10,50 \%$ dan faktor proses dan produksi dengan nilai produksi $9,00 \%$.

\section{Prioritas Tujuan Pemasaran OL UMKM Makanan}

Tujuan utama kegiatan pemasaran OL UMKM makanan adalah meningkatkan usaha. Prioritas tujuan pemasaran OL UMKM makanan lebih rinci dimuat pada Gambar 11.

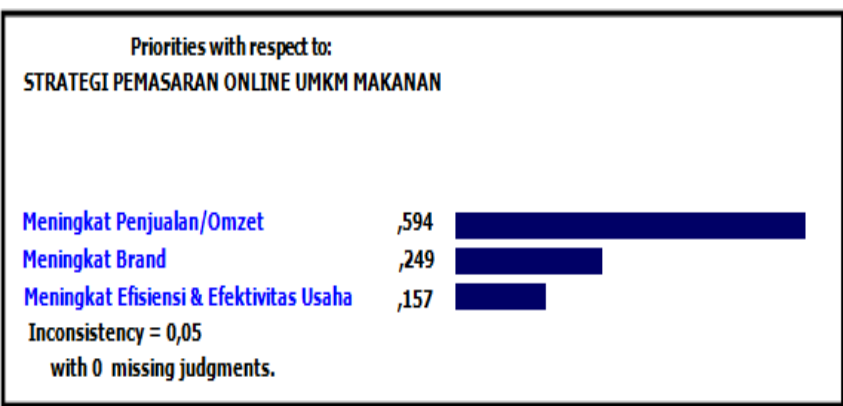

Gambar 11. Prioritas kriteria tujuan pemasaran OL UMKM makanan

Hasil menunjukkan bahwa tujuan utama dalam pemasaran OL UMKM makanan di Kecamatan Cibinong adalah meningkatkan penjualan/omzet dengan nilai persentase mencapai 59,40\%. Tujuan meningkatkan brand dari produk merupakan tujuan prioritas kedua dengan nilai persentase $24,90 \%$ dan prioritas ketiga adalah tujuan meningkatkan efisiensi dan efektivitas usaha dengan nilai persentase hanya sekitar $15,70 \%$. 


\section{Prioritas Alternatif Media Pemasaran OL UMKM Makanan}

Menurut Romli et al. (2012) bahwa media OL media massa yang tersaji secara OL di situs web (website) internet. Berdasarkan hasil survei dan pengolahan data di atas berikut disampaikan pilihan media OL dalam pemasaran UMKM makanan di Kecamatan Cibinong.

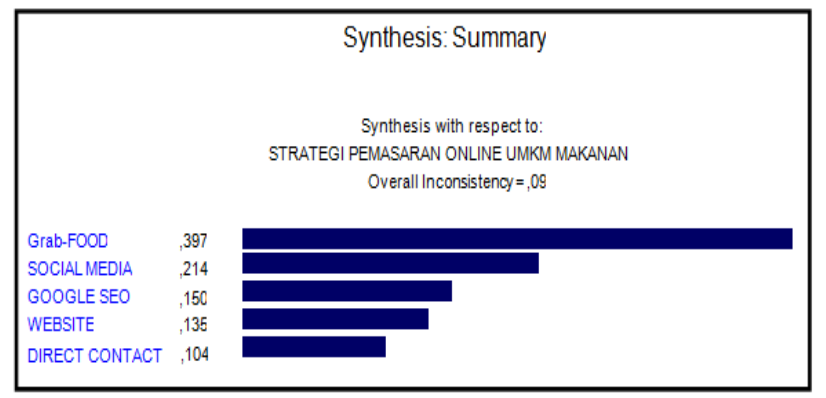

Gambar 12. Prioritas alternatif media promosi OL UMKM makanan

Hasil menunjukkan bahwa prioritas utama media pemasaran OL UMKM makanan di Kecamatan Cibinong adalah media Grab-food dengan nilai prioritas mencapai 39,70\%. Prioritas kedua menggunakan sosial media (facebook, instagram, youtube, dll) dengan nilai prioritas adalah $21,40 \%$. Prioritas ketiga adalah menggunakan media Google SEO dengan nilai prioritas sekitar 15,00\%. Prioritas keempat adalah menggunakan website dengan nilai prioritas $13,50 \%$ dan prioritas kelima adalah direct contact dengan nilai prioritas sekitar 10,40\%.

\section{KESIMPULAN}

Penelitian strategi pemasaran OL UMKM makanan di Kecamatan Cibinong memberikan kesimpulan berikut:

- Pemasaran OL telah meningkatkan pendapatan UMKM makanan responden di Kecamatan Cibinong 10-32\%.

- UMKM Makanan responden mengetahui pentingnya deskripsi dan visualisasi produk yang dipasarkan secara OL, serta telah melakukan usaha perbaikan tampilan seperti menggunakan jasa fotografer profesional dan editing.

- Pada faktor internal adalah pengetahuan dan skill SDM dalam operasional usaha; dan pada faktor eksternal adalah kemajuan TI dan inovasi menu dan produk baru.
- Kedudukan pengembangan promosi OL UMKM makanan di Kecamatan Cibinong berada dalam kuadran $\mathrm{V}$ atau fase stabilitas; dan diperoleh sembilan strategi pengembangan usaha UMKM makanan berbasis OL di Kecamatan Cibinong, yakni (a) Pengembangan Usaha dengan Dukungan SDM \& Media Pemasaran yang tersedia, (b) Pengembangan Usaha dengan Sistem (OL), (c) Peningkatan Skala Usaha dengan Memanfaatkan Modal, (d) Peningkatan Skill dan Pengetahuan Sistem OL, (e) Peningkatan Modal Usaha dan Tampilan Promosi Produk dalam peningkatan omzet, (f) Pengembangan Usaha melalui Varian Produk, Cita Rasa dan Promosi, (g) Peningkatan kapasitas usaha dan layanan (Delivery), (h) Peningkatan kerjasama promosi produk OL, (i) Peningkatan Inovasi dan varian produk baru.

\section{DAFTAR PUSTAKA}

Briggs, R. and N. Hollis. 1997. Advertising on the Web: Is there response before click through. Journal of Advertising Research; 37(1): 33-45.

David, F.R. 2010. Manajemen Strategi. Buku 1, Edisi kesepuluh. Jakarta (ID): Salemba Empat.

Marimin. 2004. Teknik dan Aplikasi Pengambilan Keputusan Kriteria Majemuk. Jakarta (ID): Grasindo.

McCoy, S., A. Everard, D. F. Galletta \& G.D. Moody. 2016. Here we go again! The impact of website ad repetition on recall, intrusiveness, attitudes, and site revisit intentions. Las Vegas (US): UNLV

Mintzberg, H. 1993. The pitfalls of strategic planning, California Management Review; 36(1): 32-47.

Rangkuti, F. 2015. Analisis SWOT: Teknik Membedah Kasus Bisnis. Gramedia Pustaka Utama. Jakarta. 246p.

Romli, A.S.M. 2012. Jurnalistik Online: Panduan Mengelola Media Online. Bandung (ID): Penerbit Nuansa.

Sari, I.I. 2012. Analisis Sembilan Iklan Produk Makanan-Minuman Organik di Jerman.Depok (ID): Universitas Indonesia.

Sugiyono. 2010. Metode Penelitian Administratif. Bandung (ID): Alfabeta.

Ustadiyanto, R. 2007. E-Business Plan: Perencanaan, Pembangunan dan Strategi di Internet. Yogyakarta (ID): Penerbit ANDI. 